\title{
The Impact of Scout Couching on the Change of Students' Behaviour in Muda Senior High Vocational School Aceh Tamiang
}

\author{
Syamsulrizal Syamsulrizal, Amiruddin Amiruddin \\ Physic, Sport and Health Education Department \\ Syiah Kuala University \\ Banda Aceh, Indonesia \\ Syamsulrizal.jantho@gmail.com,amiruddin_ulka@gmail.com
}

\begin{abstract}
Scouts are one of the elements of education in the world, in Indonesia as well. Scouting activities are always in demand at the elementary level, junior high school, senior high school, and college level. It hopes that through scouting activities will be born noble nation, responsible, disciplined and full of ethics students in social living. The purpose of this study was to determine to which extent the behaviour changes of the Muda High Vocational School's students in Aceh Tamiang by scout coaching activities at school. In this study, authors used field research techniques, by spreading the questionnaire, observation and interviews. The population of this study was all students of the Muda High Vocational School students in Aceh Tamiang, it was amounts about 80 people. The sample in this study was the entire population, 80 people, so total sampling were the sampling technique were used. Data analysis technique was done by calculating percentage value of students' knowledge who have followed scout coaching. The results showed that more than $\mathbf{5 0 \%}$ pointed to a change in social behavior towards the better and there is a change in the knowledge, skills, discipline in the daily life of the Muda Senior High Vocational School in Aceh Tamiang.
\end{abstract}

Keywords - coaching; scout; social behavior; senior high vocational school

\section{BACKGROUND OF THE STUDY}

Scouts were not an alienic term any longer in educational world, were not it in Indonesia. Scouting activities are always in demand at the Elementary, Junior High, High School, and College level. Scout Movement is the name of non-formal education organization that organizes scouting activities outside the school environment and outside the family environment in the form of interesting activities.

According to the Articles of Association (AD) and laws (ART), Scouts Movement 2013 [1], chapter 3 chapter 6:

The Scout Movement is an educational organization whose membership is of a nature voluntary, independent, nondiscriminatory, ethnic, racial, religious, and religious groups. The Scout Movement is not a socio-political organization, it is not part of one socio-political organization and does not carry out practical political activities. Scout Movement guarantees the independence of each member to embrace their respective religions and beliefs and worship according to their religion and belief.

Scouting education is the process of forming the personality, life skills, and noble character of the Scouts members through the appreciation and practice of scouting values. It is a family education system conducted in outdoor with particular forms of activities that are interesting, challenging, fun, healthy, organized, and directed, by applying the basic principles of scouting and scouting methods. It hopes to form a personality and character who is noble, independent, caring, and having life skills.

The problems faced by the Scout movement recently are the low quality of scout leaders, many coaches who have emerged because of their positions as teachers, such as class teachers and honorary teachers, who have not attended scout couching and less experience as members of the previous Scouts movement.

Their poor experience will undoubtedly result in a lack of understanding of the basic idea of scouting education. As an effort to increase the knowledge and insight of scout leader in developing the students to reach the scout movement goal, it is necessary to educate and train the Scout leaders to improve their quality, so that they understand and have ownership sense towards the scout movement. It hopes that they consciously volunteer in assisting the implementation of education and training in scout movement. Scouts also apply to the adult as a form of dedication and duty to devote himself in the community, and scout is also a society medium to develop all aspects of living.

The result of preliminary field observation indicates that the students who follow the scouting activities in the school are changing in terms of the behaviour, especially the ethics of the association, the discipline and the responsibility either to the group or to themselves. While students who do not follow the scouting activities at school are having really differences in behavior that are very different such as being absent from the class, not being on time in coming to the class in the morning. This is evident from the report of the physiologist teacher in the school. 
Based on the observations in the field, researchers found there was still a shortage of scout leaders in some schools. Based on the above background, the researcher intends to conduct research with the title "Impact of Scout Development on Change of Student Behavior in SMAN 1 Kejuruan Muda Aceh Tamiang"

\section{A. Research Problem}

Based on the background of the problem, the formulation of the problem in this study was how the impact of scout coaching on changes in student behavior in Muda Senior High Vocational School in Aceh Tamiang?

\section{B. Research Objective}

Based on the formulation of the above problem which becomes the purpose of this study is to find out to which extent the changes in the behavior of Muda senior high Vocational school's students in Aceh Tamiang.

\section{LITERATURE REVIEW}

\section{A. Understanding Scout}

Boy Scouts, is an international scouting or scout movement that aims to improve the character of children and adolescents to train them to be responsible in their adulthood. Literally scout can be interpreted as "the front". The word scout is a sequence of the words "Pra, Mu, Karana". Pra which stands for "praja" which means people or citizens. $M u$ stands for the word "young" which means immature. $\mathrm{Ka}$ stands for "karana" which means deed, income.

Scouts are a name for the scout movement's members aged between 7-25 years old and are domiciled as students, as standby, rally, enforcer and pandega. In addition, the scout is an abbreviation of young karana which have the meaning as young people who like to work and share $[1,2,3,4]$.

The Scout is a process of education outside the school and outside the family in the form of interesting, fun, healthy, organized, focused, and practical activities conducted in the outdoor by implementing the Basic Principles of Scouting and Scouting Method, the ultimate goal is the formation of character, morals, and mind noble character. Scout is a scouting education system tailored to the circumstances, interests, and development of society, and the nation of Indonesia.

\section{B. Scouting History}

The history of Scout cannot be separated from someone named Baden Powell, British soldiers born in London on February 22, 1857, who is the initiator of activities, which is famous as scout in history, scouting is written in the book Aids to scouting (1899) which contains experience story of Baden Powell when he was in the army.

The public hight interest in Aids to Scouting book led William Alexander Smith (Head of the UK Boys Brigade) to ask Baden Powell to train 22 youths. By Baden Powell, these 22 youths were invited to camp on Brownsea Island for 8 days on July 25 - August 2, 1907. Recorded in history, the camp inspired Baden Powell to write the book 'Scouting for Boys' (1908)

History records that the book "Scouting for Boys" was widespread in Britain and other countries. This book inspires the establishment of scouting organizations in the UK and beyond. So there were emerging activities for youth by applying the ideas of Baden Powell. Originally scouting was intended only for boys aged 11 to 18 years with the name Boys Scout.

In 1912 by her sister's help, Agnes took the initiative to set up a scouting organization for women under the name Girl Guides. The organization was later continued by the wife of Baden Powell. In 1916 stood the scout 'standby' age group with the name Cub (wolf boy) with the book The Jungle Book by Rudyard, this is a clipping book as a guideline of its activities. This book tells the story of Mowgli the jungle boy being kept in the forest by a wolf.

Baden Powell formed the "Rover Scout" for those who are 17 years old. In 1922, he published the book Rovering to Success (Wandering towards Happy). This book describes a young man who had to paddle his boat to a happy beach. In 1920 newly formed WOSM or World Organization of the Scout Movement which is a worldwide scout movement organization. The scouting organization in Indonesia was initiated by the branch of the Nederlandse Padvinders Organisatie (NPO) in 1912, which at the time of the outbreak of World War I had its own big kwartir and later renamed "Nederlands-Indische Padvinders Vereeniging" (NIPV) in 1916.

The figures of the Indonesian national movement formed a scouting organization that aims to form a good Indonesian youth and become a cadre of national movement. As a result, there were indigenous scouting organizations that reached more than a hundred organizations at that time. Organization such as; JPO (Javanese Padvinders Organizatie); JPP (Jong Java Padvinderij), SIAP (Sarekat Islam Afdeling Padvinderij); HW (Hisbul Wathon) etc.

In the president Speech on March 9, 1961, it also outlined that on the anniversary of the Proclamation of Independence of Indonesia Scout Movement must have been established and known by the society. Therefore Presidential Decree No.238 of 1961 needed to have supporters of the board and its members. According to the Statutes of Scout Movement, leaders of this association is held by the National Leadership Council (MAPINAS) in which is a National Scout Movement and the National Scouts Kwartir Daily.

The Central Executive Board was symbolically arranged by taking the sacred number 17-8-'45, which consists of Mapinas consisting of 45 people of whom sitting in Kwarnas 17 people and in Kwarnasri 8 people. The first Mapinas was led by Dr. Ir. Soekarno, Vice Chairman I, Sri Sultan Hamengku Buwono IX and Vice Chairman II Brig. Gen. Dr.A. Aziz Saleh. Meanwhile in Kwarnas, Sri Sultan Hamengkubuwono IX served as chairman and Brig. Aziz Saleh was as a representative.

The Scout Movement was officially introduced to all Indonesians on August 14, 1961 not only in the capital Jakarta, but also in important places in Indonesia. In Jakarta about 
10,000 members of the Scout Movement held a big muster followed by a development parade, a defile in front of the President and around Jakarta.

Before the parade or defile, the President inaugurated the members of Mapinas and Kwarnas at the State Palace, and conveyed the award of honor and honor in the form of Panji National Indonesian Scout Movement (Keppres No.448 of 1961) which was received to the Chairman of the National Kwartir, Sri Sultan Hamengku Buwono IX before the march / defile begins. The event of introduction on August 14, 1961 was then performed as a scout day which is annually commemorated by the whole range and members of the Scout Movement in Indonesia.

\section{RESEARCH METHOD}

This study authors used field research techniques, by spreading the questionnaire.

\section{A. Population and Sample}

The population in this study were high school students of Muda Senior High Vocational School in Aceh Tamiang which amounted to 80 people. The sample in this study was the entire population of 80 people. Sampling technique used was total sampling.

\section{B. Data Collection Technique}

Arikunto [5] "Questionnaire or commonly called a questionnaire is a list of questions that are given to others who are willing to respond in accordance with user requests. Questionnaires or questionnaires used in this study was a type of questionnaire or direct questionnaire that was closed because the respondent only left to sign on one of the answers that were considered correct. Further Sugiyono [6] states that "the questionnaire is a data collection technique that was done by giving a set of questions or written statement to the respondent to answer"

\section{Data Analysis Technique}

Data processing is a concrete effort to make the data useful, because the amount and function of data collected if not processed and arranged in a sequence regularly undoubtedly the data was not useful at all. As expressed by Azwar [7], to find the data obtained then must use the formula Percentage.

\section{RESUlT AND DISCUSSION}

\section{A. Result}

By collecting data with questionnaires to students about scouting knowledge can be seen very significant results. From this research students were expected to be students who have some elements in the development of scouts include: 1) gratitude to the most omnipotent God who has created the universe with a form of love to the environment and society, 2) build a good personality for themselvesself, work in teamwork, emotional control, cultivating the spirit of gotong royong (togetherness) and deliberation, 3) developing discipline, knowledge, skills, leadership and confidence.

\section{Personality}

Yes No

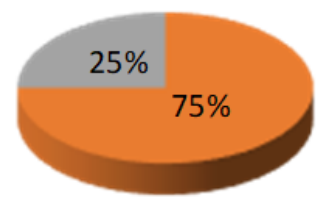

Fig. 1. Personality.

Based on fig. 1data it could be known that the personality development from scouting as much as 60 people answered yes or $75 \%$, and 20 people stated no or $25 \%$, this shows the ability of students in terms of personality, among others: independence, cooperation control emotions, gotong royong and deliberation.

\section{Discipline}

Yes $\square$ No

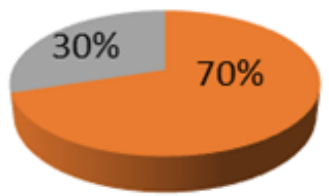

Fig. 2. Discilpline

Based on fig. 2 the level of discipline of students who have followed the scouting which includes the obedience element of discipline and obedience in scout coaching that took place in school 56 people or $70 \%$ said yes, and 24 people or $30 \%$ said no.

\section{Knowledge}

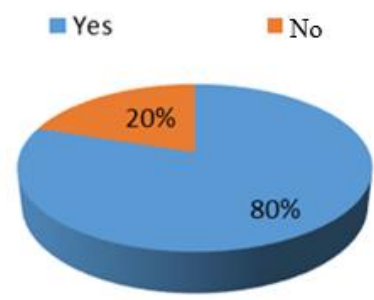

Fig. 3. Knowledge

Based on fig. 3 the level of Knowledge of students who have followed scout coaching which includes elements of scout history, scouting goals, scouting materials, scout duties and responsibilities 64 people or $80 \%$ say yes, and 14 people or $20 \%$ say no. 
Skills

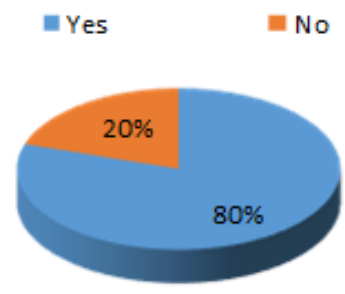

Fig. 4. Skills.

Based on fig. 4 the skill level of students who have followed the scouting that includes skill elements in ropes, sticks, flags and using a compass 64 people or $80 \%$ say yes, and 14 people or $20 \%$ say no.

\section{Confidence}

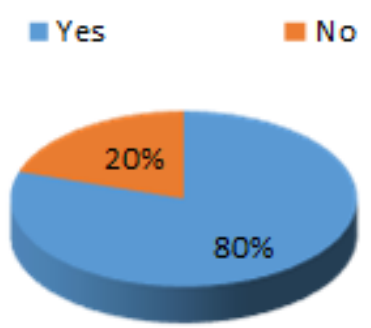

Fig. 5. Confidence.

Based on fig. 5 the level of leadership of students who have followed the scouting which includes the ability to be a role model for other Scout members, the ability to be leaders and able to take the attitude and decision 64 people or $80 \%$ said yes, and 14 people or $20 \%$ said no.

\section{B. Discussion}

The results obtained showed that students who followed the scouting which included personality, discipline, knowledge, skills, confidence showed significant results, on average more than $50 \%$ of students understood the five elements in scouting so it was positive for students in every school.

\section{Suggestion}

Based on the results of the research, the suggestions referred to this study as a continuous first step in scouting to improve the quality and professionalism of students in all schools in order to be able to provide changes in behavior so that impact on daily activities.

\section{CONCLUSION AND SUGGESTION}

\section{A. Conclusion}

There were 5 main aspects of students'behaviour that are changed by doing scout activities, such as; personality, dicipline, knowledge, skills, and confidence. The research result showed that more than $50 \%$ of participant agreed that the scouting activities help them to change their social behavior to be better as the students of Muda Senior High Vocational School in Aceh Tamiang.

\section{B. Suggestion}

Based on the results of the research, the suggestions referred to this study as a continuous first step in scouting to improve the quality and professionalism of students in all schools in order to be able to provide changes in behavior so that impact on daily activities.

\section{.REFERENCES}

[1] Kwarnas Gerakan Pramuka. Anggaran Dasar Dan Anggaran Rumah Tangga Gerakan Pramuka. Jakarta, 2013.

[2] S. Rinaldi. Tingkat Kebugaran Jasmani Anggota Pramuka SMP PKPU Aceh Besar Tahun ajaran 2016/2017. Skripsi. FKIP. UNSYIAH. Banda Aceh. 20017.

[3] S. A. Bob. Boyman. Bandung : Penerbit Nusa Muda. 2010.

[4] Sudjana. Penilaian Hasil Proses Belajar Mengajar. Bandung: PT. Remaja Rosdakarya. 1995.

[5] Arikunto, S., Prosedur Penelitian Suatu Pendekatan Praktek. Jakarta:Rineka Cipta. 2010.

[6] Sugiyono. Metode penelitian Kuantitatif Kualitatif dan R\&D. Bandung: Alfabeta. 2012.

[7] Azwar, S., "Metode Penelitian. Cet: VII." Yogyakarta: TNP, 2007. 